Edith Cowan University

Research Online

Research outputs 2014 to 2021

$1-31-2019$

\title{
Global access to antibiotics without prescription in community pharmacies: A systematic review and meta-analysis
}

Asa Auta

Muhammad A. Hadi

Enoche Oga

Emmanuel O. Adewuyi

Edith Cowan University

Samirah N. Abdu-Aguye

See next page for additional authors

Follow this and additional works at: https://ro.ecu.edu.au/ecuworkspost2013

Part of the Public Health Commons

10.1016/j.jinf.2018.07.001

Auta, A., Hadi, M. A., Oga, E., Adewuyi, E. O., Abdu-Aguye, S. N., Adeloye, D., ... Morgan, D. J. (2019). Global access to antibiotics without prescription in community pharmacies: A systematic review and meta-analysis. Journal of Infection, 78(1), 8-18. https://doi.org/10.1016/j.jinf.2018.07.001

This Journal Article is posted at Research Online.

https://ro.ecu.edu.au/ecuworkspost2013/10825 
Authors

Asa Auta, Muhammad A. Hadi, Enoche Oga, Emmanuel O. Adewuyi, Samirah N. Abdu-Aguye, Davies Adeloye, Barry Strickland-Hodge, and Daniel J. Morgan 
(C) 2019. This manuscript version is made available under the CC-BY-NC-ND 4.0 license http://creativecommons.org/licenses/by-nc-nd/4.0/ 
Global access to antibiotics without prescription in community pharmacies: a systematic review and meta-analysis

Asa Auta ${ }^{1 *}$, Muhammad Abdul $\mathrm{Hadi}^{2}$, Enoche Oga ${ }^{1}$, Emmanuel O. Adewuyi ${ }^{3}$, Samirah N. Abdu-Aguye $^{4}$, Davies Adeloye ${ }^{5}$, Barry Strickland-Hodge ${ }^{6}$, Daniel J. Morgan ${ }^{7,8}$

${ }^{1}$ School of Pharmacy and Biomedical Sciences, University of Central Lancashire, Preston, PR1 2HE, United Kingdom

2Leicester School of Pharmacy, De Montfort University, Hawthorn Building, Leicester LE1 9BH, United Kingdom

${ }^{3}$ Statistical and Genomic Epidemiology Laboratory, Institute of Health and Biomedical Innovation, Queensland University of Technology, Brisbane, Australia.

${ }^{4}$ Department of Clinical Pharmacy and Pharmacy Practice, Faculty of Pharmaceutical Sciences, Ahmadu Bello University, Zaria, Nigeria

${ }^{5}$ Centre for Global Health Research and the World Health Organization Collaborating Centre for Population Health Research and Training, Usher Institute, University of Edinburgh, UK. ${ }^{6}$ School of Healthcare, Faculty of Medicine and Health, University of Leeds, Leeds, LS2 9JT, UK.

${ }^{7}$ Department of Epidemiology and Public Health, University of Maryland School of Medicine and the VA Maryland Healthcare System, Baltimore, MD, USA

${ }^{8}$ Centers for Disease Dynamics, Economics and Policy (CDDEP), Washington DC, USA.

${ }^{*}$ Corresponding author: Asa Auta, School of Pharmacy and Biomedical Sciences, University of Central Lancashire, Preston, PR1 2HE, UK. Email: aauta@uclan.ac.uk 


\section{Abstract}

Objective: To estimate the proportion of over-the-counter antibiotic requests or consultations that resulted in non-prescription supply of antibiotics in community pharmacies globally.

Methods: We systematically searched EMBASE, Medline and CINAHL databases for studies published from January 2000 to September 2017 reporting the frequency of non-prescription sale and supply of antibiotics in community pharmacies across the world. Additional articles were identified by checking reference lists and a Google Scholar search. A random effects meta-analysis was conducted to calculate pooled estimates of non-prescription supply of antibiotics.

Results: Of the 3302 articles identified, 38 studies from 24 countries met the inclusion criteria and were included in the review. All the included countries with the exception of one, classified antibiotics as prescription-only medicines. The overall pooled proportion of non-prescription supply of antibiotics was $62 \%(95 \% \mathrm{Cl} 53-72)$. The pooled proportion of non-prescription supply of antibiotics following a patient request was $78 \%(95 \% \mathrm{Cl} 59-97)$ and based on community pharmacy staff recommendation was $58 \%(95 \% \mathrm{Cl} 48-68)$. The regional supply of non-prescription antibiotics was highest in South America, 78\% (95\% Cl 72 - 84). Antibiotics were commonly supplied without a prescription to patients with symptoms of urinary tract infections $(68 \%, 95 \% \mathrm{Cl} 42-93)$ and upper respiratory tract infections $(67 \%, 95 \% \mathrm{Cl} 55-79)$. Fluoroquinolones and Penicillins respectively were the most commonly supplied antibiotic classes for these indications.

Conclusion: Antibiotics are frequently supplied without prescription in many countries. This overuse of antibiotics could facilitate the development and spread of antibiotic resistance.

Keywords: antibiotics; non-prescription supply; community pharmacies; infections; antibiotic stewardship. 


\section{Introduction}

Antibiotics are the most frequently prescribed medicines world-wide. ${ }^{1}$ Between 2000 and 2010, consumption of antibiotics increased from approximately 50 billion to 70 billion standard units. ${ }^{1}$ More than three-quarters of the overall increase in consumption of antibiotics occurred in Brazil, Russia, India, China, and South Africa. ${ }^{1}$ This global increase in consumption has been driven by a number of factors including economic growth and access to antibiotics. ${ }^{1}$

However, the growing access to and use of antibiotics (either through prescription or nonprescription) has been linked to antibiotic resistance, which is a significant threat to global public health. ${ }^{1-3}$ Antibiotic resistance accounts for more than 2 million infections and at least 23,000 deaths annually in the USA ${ }^{4}$ and about 25,000 deaths in Europe ${ }^{5}$. Although reliable estimates of the burden of antibiotic-resistant infections in developing countries are lacking, it is believed to cause many more deaths in these countries. For example, in India alone, about 57,000 neonatal sepsis deaths occurring annually are due to antibiotic-resistant infections. ${ }^{5}$

About $80 \%$ of antibiotics are used in the community. ${ }^{6}$ These antibiotics are either prescribed by a healthcare professional or purchased directly by consumers without a valid prescription from many sources including community pharmacies. In many countries, the dispensing of antibiotics without a prescription is illegal. Nevertheless, over $50 \%$ of antibiotics worldwide are obtained without a prescription and community pharmacies are a major source of nonprescribed antibiotics. ${ }^{7}$ This practice is particularly common in developing countries where there are no regulations regarding the sale and distribution of medicines or the enforcement of these regulations is weak. ${ }^{8,9}$ Recent evidence has indicated that dispensing antibiotics without a prescription is becoming a problem in developed countries including Portugal and Spain. ${ }^{10,11}$

Non-prescription use of antibiotics is often associated with incomplete/shorter treatment courses and inappropriate drug and dose choices. ${ }^{12-14}$ Such irrational use of antibiotics could have a number of consequences including the development and spread of resistance to antibiotics, delayed hospital admissions and masking the diagnosis of infectious diseases. ${ }^{12-}$ 15 For example, tuberculosis symptoms suppressed temporarily through the use of fluoroquinolones could delay its diagnosis and lead to the patients receiving several antibiotic courses for the wrong diagnosis. ${ }^{15}$ While in recent times, several interventions designed to optimise the use of antibiotics have been developed, they are often targeted at hospitals thereby missing the non-prescription sources of antibiotics. ${ }^{16}$

To address the problem of non-prescription use of antibiotics, an understanding of the magnitude of the practice and circumstances in which it occurs is important in the first instance. Previous reviews have focussed on the frequency of non-prescribed use of 
antibiotics in the general population and have identified community pharmacies as important sources of these antibiotics. ${ }^{16,17}$ However, the review by Morgan et al., ${ }^{16}$ provided additional analysis on the frequency of community pharmacists' recommendation of non-prescribed antibiotics. The analysis by Morgan et al., ${ }^{16}$ was limited to 13 studies and without specific estimates by country, region or symptom. Hence, a more robust and updated analysis is needed. Therefore, we estimated the frequency of the supply of antibiotics without a prescription in community pharmacies globally identifying regions where this practice commonly occurs, the disease conditions commonly treated with non-prescribed antibiotics and the types of antibiotics commonly supplied without a prescription in community pharmacies.

\section{Methods}

\section{Search strategy}

We searched EMBASE, Medline and CINAHL to identify studies published from January 2000 to September 2017 that reported the sale and dispensing of non-prescribed antibiotics in community pharmacies. Search terms used including antibiotics, community pharmacy, sales and dispensing were combined using Boolean operators (See Box1). Additional articles were identified by checking reference lists and Google scholar search. No language or geographical restrictions were applied to the search. The research protocol was registered in the PROSPERO international prospective register of systematic reviews (CRD42017058156).

\section{Eligibility criteria for included studies}

Two reviewers, AA and DA independently screened studies against the inclusion and exclusion criteria with a Kappa agreement of $91.9 \%$. Discrepancies were resolved through consensus. We included observational and experimental studies that reported the proportion of over-the-counter antibiotic requests or consultations in relation to symptoms of suspected infectious diseases that resulted in non-prescription supply of antibiotics in community pharmacies. Population-based surveys that explored pharmacists' and public opinions on the supply and/or sources of non-prescription antibiotics were excluded. We also excluded qualitative studies (with no quantitative measures of non-prescription supply of antibiotics), reviews, editorials and conference reports.

\section{Assessment of risk of bias of included studies}

All studies were assessed for quality and risk of bias on eight criteria modelled largely from the 'Strengthening the Reporting of Observational Studies in Epidemiology framework'. ${ }^{18}$ These criteria were: detailed description of research setting, sample size, sampling strategy, clear definition of clinical/product-request scenario, reliability of measurement, social 
desirability, statistical analysis methods and generalisability of results. Each risk of bias criteria was assessed as low (scored as 1), moderate/high or unclear (scored as 0 ). The total score for each study was computed. All studies were classified into one of the three levels of bias depending on their total scores, 0-2 (high risk), 3-5 (moderate risk) and 6-8 (low risk).

\section{Data extraction}

Data were extracted by two reviewers (AA \& DA) and any discrepancy was resolved by consensus. The following data were extracted; author, year of publication, study country, sample size, number of visits/interactions observed, proportion of non-prescribed sale and supply of antibiotics. Other data extracted include types of symptoms/disease conditions treated, types of antibiotics dispensed and nature of information given during consultation.

\section{Data analysis}

Statistical analyses were performed using Stata version 13.1 (StataCorp. LP, College Station, USA). A random effects meta-analysis based on the DerSimonian and Laird approach, ${ }^{19}$ was conducted to calculate pooled proportions (with 95\% confidence interval) of the supply of non-prescribed antibiotics for all included studies. The proportion of non-prescription supply of antibiotics in this study was calculated as the percentage of over-the-counter antibiotic requests or consultations in relation to symptoms of infectious diseases that resulted in the supply of antibiotics without a prescription. Proportion data were also pooled by symptoms of disease conditions, study period and types of antibiotics dispensed. I-squared $\left(I^{2}\right)$ statistics were determined to assess the degree of heterogeneity across studies. Sub-group and metaregression analyses were conducted to explore the causes of heterogeneity. The co-variates considered included geographical region, study period, sampling procedure (random vs convenience sampling), number of community pharmacies, type of simulated scenario, category of pharmacy staff, concealment in methodology and each risk of bias criteria. Covariates were first tested individually and only those with $p$-values below 0.01 were included in the multivariate model. We performed sensitivity analysis to examine the effect of outliers and test the robustness of our findings.

\section{Results}

\section{Study selection and characteristics}

We identified 3302 articles through the literature search, of which 38 met the inclusion criteria (see figure 1). The 38 studies were conducted in 24 countries and involved 8085 interactions within 6353 community pharmacies. Antibiotics are classified as prescription-only medicines in all the countries included in this review with the exception of Thailand. In Thailand, pharmacists are legally allowed to supply some antibiotics without a prescription. 
The majority of the studies (23 out of 38 ) included in this review were conducted in Asia. Almost all (37 out of 38 ) of the included studies were of cross-sectional design (Table 1). All included studies used simulated patient methodology with 35 of the 38 studies involving simulated-patient with concealed identities. The remaining three studies were based on pharmacy staff interviews using simulated scenarios. A range of scenarios were simulated in the included studies with the most common involving symptoms of upper respiratory tract infections (URTI), gastroenteritis and urinary tract infections (UTI) in women of childbearing age (Table 1).

The risk of bias assessment found that 15 (39\%) studies had a low risk of bias while the remaining $23(61 \%)$ studies had a moderate risk. The most common source of bias among the included studies was due to sampling $(26 / 38,68 \%)$ and half of the included articles (19/38) did not report a justification for the sample sizes used in their studies.

\section{Pooled estimates of the supply of antibiotics without prescription}

The overall pooled estimate of non-prescription supply of antibiotics was $62 \%$ (95\% Cl 53 72) (Figure 2). This global estimate was comparable to the estimate for Asia (65\%, 95\% Cl 54 - 76), the most studied region. The pooled estimate for Southern and Eastern Europe (53\%, $95 \% \mathrm{Cl} 33-72)$ was comparable to that of Africa $(57 \% 95 \% \mathrm{Cl} 16-99)$. The pooled estimate for Africa, was lower than those for Asia $(65 \%, 95 \% \mathrm{Cl} 54-76)$ and South America (78\% 95\% $\mathrm{Cl} 72$ - 84). This was due to the low prevalence in the Zimbabwean study (Figure 2). Sensitivity analysis conducted by excluding the Zimbabwean study yielded a pooled estimate of $74 \%$ (95\% Cl $63-85)$ for Africa. However, the overall proportion (64\%, 95\% Cl $55-73$ ) of nonprescription supply of antibiotics in community pharmacies was similar to the estimate obtained before the sensitivity analysis. Generally, non-prescription supply of antibiotics was more frequent in Indonesia $(91 \%, 95 \% \mathrm{Cl} 86$ - 94), Syria (87\%, 95\% Cl 82 - 91), Saudi Arabia (85\% 95\% Cl 72 - 99) and Ethiopia (85\% 95\% Cl 75 - 92) (Figure 3).

Seven studies presented data on the proportion of non-prescription supply of antibiotics following a specific product request by patients. The figures ranged from $16 \%(95 \% \mathrm{Cl} 10-$ $22)$ in Spain ${ }^{20}$ to $98 \%$ (95\% Cl 94 - 102) in Saudi Arabia ${ }^{21}$. The pooled estimate was $78 \%$ (95\% CI 59 - 97). Similarly, the proportion of non-prescription supply of antibiotics based on pharmacy staff recommendation following the presentation of clinical symptoms to them ranged from $8 \%$ (95\% Cl 4 -12) in Zimbabwe ${ }^{22}$ to $94 \%$ (95\% Cl $\left.92-98\right)$ in India ${ }^{23}$. The pooled estimate based on pharmacy staff recommendation was $58 \%$ (95\% Cl $48-68)$ (Figure 4).

Subgroup meta-analysis showed a significant difference between the pooled proportions of studies conducted from $2000-2005$ and $2011-2017$ with estimates of $80 \%(95 \% \mathrm{Cl} 76-85)$ and $56 \%(95 \% \mathrm{Cl} 43-69)$, respectively (Table 2). Overall, substantial heterogeneity was 
observed on the pooled estimate of non-prescription supply of antibiotics ( $X^{2}=4239.0, p<$ $\left.0.001, I^{2}=99.1 \%\right)$. Of the sources of variation investigated through meta-regression, only number of community pharmacies, study period and three quality criteria (reliability of measurement, statistical analysis methods and generalisability of results) had $p$ values below 0.10 . These covariates yielded a significant multivariate model $(p=0.0193)$ that explained $25.3 \%$ of between-study variation.

\section{Pooled estimates by symptom category}

The proportion of non-prescription supply of antibiotics among patients with symptoms of upper respiratory tract infections (URTI) ranged from $19 \%(95 \% \mathrm{Cl} 15-22)$ in a study in Bosnia and Herzegovina ${ }^{24}$ to $99 \%(95 \%$ Cl $97-100)$ in Vietnam ${ }^{25}$. The pooled estimate for URTI was $67 \%$ (95\% CI 55 - 79) (Table 3). Penicillins were the most commonly recommended and supplied medicines to treat symptoms of URTI (Figure 5). Pooled analysis by individual type of antibiotics supplied revealed that amoxicillin 53\% (95\% Cl 34-71; $\left.I^{2}=98.0, p<0.001\right)$, amoxicillin-clavulanic acid (co-amoxiclav) 39\% (95\% Cl 23-54; $\left.I^{2}=97.4, p<0.001\right)$ and azithromycin 19\% (95\% Cl 11-27; $\left.\left.\right|^{2}=96.2, p<0.001\right)$ were commonly supplied for URTI.

The pooled estimates of non-prescription supply of antibiotics to patients with symptoms of urinary tract infections (UTI) and acute gastroenteritis were $68 \%(95 \% \mathrm{Cl} 42-93)$ and $63 \%$ (95\% Cl 46-80), respectively. Fluoroquinolones (69\%, 95\% Cl 50-88) including ciprofloxacin and norfloxacin were commonly supplied for UTI while metronidazole (55\%, 95\% CI 29-81) was the most commonly supplied non-prescription antibiotic for acute gastroenteritis.

Two studies investigated non-prescription supply of antibiotics in patients with persistent pulmonary tuberculosis. The proportions of non-prescription supply of antibiotics in these studies were $27 \%(95 \% \mathrm{Cl} 25-30)$ and $24 \%(95 \% \mathrm{Cl} 18-31)$ in India and Cambodia, respectively.

\section{Nature of consultation and advice given}

The proportion of patients that were referred to a medical prescriber without supplying an antibiotic ranged from $3 \%(95 \% \mathrm{Cl} 1-6)$ in a study in Indonesia ${ }^{26}$ to $38 \%(95 \% \mathrm{Cl} 35-40)$ in a study in India. ${ }^{15}$ The pooled estimate for referral was $21 \%(95 \% \mathrm{Cl} 14-28)$.

Very few consultations that resulted in non-prescription supply of antibiotics enquired about the patients' drug history $(12 \%, 95 \% \mathrm{Cl} 4-19)$ and allergies $(32 \%, 95 \% \mathrm{Cl} 11-53)$ (Table 4$)$. The pooled proportion of the number of consultations with pharmacy staff that resulted in the provision of information regarding the dose and duration of treatment with the supplied antibiotics were $73 \%(95 \% \mathrm{Cl} 52-92)$ and $49 \%$ (95\% Cl 28-70), respectively. Four studies reported on the proportion of women of childbearing age presenting with symptoms of UTI that 
were asked about their pregnancy status prior to antibiotics being supplied. The proportion ranged from $0 \%$ in a Spanish study ${ }^{10}$ to $23 \%$ in a Saudi Arabian study. ${ }^{27}$

\section{Discussion}

This is the first study to provide pooled estimates of the extent of the supply of antibiotics without prescription. Despite regional variations, supplying antibiotics without prescription remains high globally. About three in four (78\%) antibiotic requests and three in five $(60 \%)$ consultations (in relation to symptoms of infectious diseases) in community pharmacies resulted in the supply of antibiotics without prescription. The majority of these antibiotics were supplied for the treatment of disease conditions that were largely acute and self-limiting including upper respiratory tract infections and gastroenteritis.

Many of the antibiotics supplied without a prescription were broad-spectrum antibiotics including amoxicillin, amoxicillin-clavulanic acid, azithromycin and several fluoroquinolones. The use of broad-spectrum antibiotics increases the risk of the development of resistant infection including methicillin-resistant Staphylococcus aureus (MRSA). Broad-spectrum antibiotics were commonly recommended even in conditions where there are equally effective narrow spectrum antibiotics which can be used as first line therapies. For instance, fluoroquinolones were commonly recommended and supplied for uncomplicated urinary tract infections rather than the first-line narrow spectrum antibiotics such as trimethoprim and nitrofurantoin. Such use of fluoroquinolones can promote the development of resistant UTIs. A recent systematic review and meta-analysis estimating the global prevalence of antibiotic resistance in paediatric urinary tract infections caused by E.coli reported a pooled prevalence of $53.3 \%$ and $79.8 \%$ against ampicillin, and $2.1 \%$ and $26.8 \%$ against ciprofloxacin in OECD countries and countries outside OECD respectively. ${ }^{28}$ Over the counter sale of antibiotics in developing countries (outside OECD) was one of the reasons given by the authors to explain the higher prevalence of resistance. ${ }^{28}$

Furthermore, the majority of the commonly supplied non-prescription antibiotics identified in our review including amoxicillin, azithromycin and the fluoroquinolones have been classified by the World Health Organisation as critically important antibiotics. ${ }^{29}$ This is because of their unique place in the treatment of infectious diseases including being the sole or one of the limited therapies for serious infections. For instance, macrolides remain part of a limited treatment option for Campylobacter infections especially in children, in whom fluoroquinolones are contraindicated. ${ }^{29}$ Therefore, the emergence of resistance to these antibiotics could have a significant impact on population health given the high and increasing incidence of campylobacter infections in children especially Campylobacter jejuni. ${ }^{30}$ 
Results of this study also highlight some concerns around the safe supply and use of antibiotics. Even though the safety of fluoroquinolones in pregnancy have not been fully established, they were commonly supplied for UTIs to simulated patients who were of childbearing age without any check on their pregnancy status. In addition, only about one in three patients were asked if they have any known drug allergy during consultations. While antibiotics are largely perceived to be generally safe, serious adverse reactions including anaphylaxis have been associated with many of them. ${ }^{31}$ Therefore, we recommend that all antibiotics dispensing should have questions about allergy and pregnancy status in cases of women of childbearing age to enhance their safe use.

Strict implementation of restrictions on over-the-counter sales of antibiotics has been shown to be effective in reducing non-prescription antibiotic consumption in Brazil, Chile and South Korea and Mexico. ${ }^{32-34}$ Given that many countries have laws prohibiting over-the-counter sales of antibiotics, there is a need to ensure that these laws are strictly enforced. However, it is important to understand that over-the-counter sale of some antibiotics may be supported in certain contexts. For example, in the UK, pharmacists legally supplied using a patient group direction, azithromycin to patients with positive chlamydia test results. ${ }^{35}$ Legislative changes in some countries including Canada and New Zealand have given designated pharmacists the authority to prescribe and dispense antibiotics for some conditions. For instance, in New Zealand, pharmacists can prescribe and dispense trimethoprim for short-term treatment of an uncomplicated UTI. ${ }^{35}$

Timely access and appropriate use of antibiotics have been associated with positive patient outcomes in several serious bacterial infections including pneumonia. ${ }^{36}$ A significant proportion of deaths caused by infections in many developing countries can be averted with early diagnosis and treatment. However, in many of these countries, access to healthcare facilities and prescribers are limited. Community pharmacies are often the first point of contact for the public. ${ }^{35,37}$ Therefore, community pharmacists trained in antibiotic stewardship in these settings could play a significant role in ensuring prompt access to and rational use of antibiotics. They could deliver treatment for certain bacterial infections using standard treatment protocols, counsel patients on appropriate use of antibiotics, and prevent unnecessary use of antibiotics for non-bacterial infections through appropriate treatment of symptoms and counselling of patients to ensure they have a good understanding of their illness. ${ }^{35}$ Hence, promoting rational use of antibiotics rather than just restricting the supply of antibiotics without a prescription may be a more appropriate focus for any relevant policy in these settings. 
Finally, our study was limited by a lack of data from many countries. In addition, in countries where data were available, we included many small local/regional studies which may not necessarily reflect the extent of non-prescription supply of antibiotics across the whole nation. Geographical variations (urban vs rural) within the same country in terms of non-prescription supply of antibiotics cannot be ruled out. Therefore, our findings may have over or underrepresented the actual extent of non-prescription supply of antibiotics. Our findings could not take into account the impact of any national/regional policies targeted at reducing the supply of antibiotics without prescription, which was implemented after the publication of the included papers and has resulted in the reduction of non-prescription supply of antibiotics. We only looked at the supply of antibiotics without prescription but not antifungals or antivirals, which will be the focus of future research. Also, our aim was to estimate the global frequency of supplying antibiotics without a prescription but not to assess the association between nonprescription supply of antibiotics and development of antibiotic resistance, an important area for future research.

\section{Conclusion}

This review provides the most robust and up-to-date global estimate of the proportion of overthe-counter consultations and antibiotic requests that resulted in the dispensing of antibiotics without a prescription. Despite the limitation of our review, the findings suggest that antibiotics are frequently supplied without prescription in many countries even where this supply remains illegal. This overuse of antibiotics could facilitate the development and spread of antibiotic resistance. Our findings underscore the need for countries to enforce laws that limit the supply of antibiotics without prescription in community pharmacies.

\section{Funding}

This research did not receive any grant from funding agencies in the public, commercial, or not-for-profit sectors.

\section{Conflicts of interests}

The authors declare that they have no conflicts of interests.

\section{Contributors}

AA conceived and designed the study. All authors oversaw its implementation. AA, DA, MAH \& EO were involved in the review activities including searches, study selection, data extraction and quality assessment. AA \& DA planned and carried out the meta-analyses and meta-regressions. AA and MAH wrote the initial draft and all authors contributed writing to 
subsequent versions of the manuscript. All authors reviewed the study findings and read and approved the final version of the manuscript before submission.

\section{References}

1. Van Boeckel TP, Gandra S, Ashok A, Caudron Q, Grenfell BT, Levin SA, Laxminarayan R. Global antibiotic consumption 2000 to 2010: an analysis of national pharmaceutical sales data. Lancet Infect Dis. 2014;14(8):742-750.

2. Laxminarayan R, Heymann DL. Challenges of drug resistance in the developing world. BMJ. 2012;344:e1567.

3. Albrich WC, Monnet DL, Harbarth S. Antibiotic selection pressure and resistance in Streptococcus pneumoniae and Streptococcus pyogenes. Emerg Infect Dis. 2004;10(3):514-7.

4. Centers for Disease Control and Prevention, Antibiotic resistance threats in the United States, 2013. Available from: https://www.cdc.gov/drugresistance/pdf/arthreats-2013-508.pdf [Accessed 23 May 2017]

5. Laxminarayan R, Duse A, Wattal C, Zaidi AK, Wertheim HF, Sumpradit N, et al. Antibiotic resistance-the need for global solutions. Lancet Infect Dis. 2013;13(12):1057-98.

6. Kotwani A, Holloway K. Trends in antibiotic use among outpatients in New Delhi, India. BMC Infect Dis. 2011;11:99

7. Cars $O$, Nordberg P. Antibiotic resistance-The faceless threat. International Journal of Risk and Safety in Medicine, 2005;17(3):103-110.

8. Hadi MA, Karami NA, Al-Muwalid AS, Al-Otabi A, Al-Subahi E, Bamomen A, et al. Community pharmacists' knowledge, attitude, and practices towards dispensing antibiotics without prescription (DAwP): a cross-sectional survey in Makkah Province, Saudi Arabia. Int J Infect Dis. 2016 Jun;47:95-100.

9. Auta A, Banwat S, Dayom D, Shalkur D, Avu M. Occurrence and treatment of common health problems in a nigerian community. J Young Pharm. 2012;4(1):49-53.

10. Guinovart MC, Figueras A, Llor C. Selling antimicrobials without prescription - Far beyond an administrative problem. Enferm Infecc Microbiol Clin. 2016;S0213005X(16)30321-4.

11. Roque F, Soares S, Breitenfeld L, Figueiras A, Herdeiro MT. Influence of community pharmacists' attitudes on antibiotic dispensing behavior: a cross-sectional study in Portugal. Clin Ther. 2015;37(1):168-77.

12. Awad A1, Eltayeb I, Matowe L, Thalib L. Self-medication with antibiotics and antimalarials in the community of Khartoum State, Sudan. J Pharm Pharm Sci. 2005;8(2):326-31.

13. Apisarnthanarak A, Tunpornchai J, Tanawitt K, Mundy LM. Nonjudicious dispensing of antibiotics by drug stores in Pratumthani, Thailand. Infect Control Hosp Epidemiol. 2008;29(6):572-5.

14. Saengcharoen W, Lerkiatbundit S. Practice and attitudes regarding the management of childhood diarrhoea among pharmacies in Thailand. Int J Pharm Pract. 2010;18(6):323-31.

15. Satyanarayana S, Kwan A, Daniels B, Subbaraman R, McDowell A, Bergkvist S. Use of standardised patients to assess antibiotic dispensing for tuberculosis by pharmacies in urban India: a cross-sectional study. Lancet Infect Dis. 2016;16(11):1261-1268. 
16. Morgan DJ, Okeke IN, Laxminarayan R, Perencevich EN, Weisenberg S. Nonprescription antimicrobial use worldwide: a systematic review. Lancet Infect Dis. 2011;11(9):692-701.

17. Ocan M, Obuku EA, Bwanga F, Akena D, Richard S, Ogwal-Okeng J, et al. Household antimicrobial self-medication: a systematic review and meta-analysis of the burden, risk factors and outcomes in developing countries. BMC Public Health. 2015;15:742.

18. Vandenbroucke JP, Von Elm E, Altman DG, Gøtzsche PC, Mulrow CD, Pocock SJ, et al. Strengthening the Reporting of Observational Studies in Epidemiology (STROBE): explanation and elaboration. PLoS Med. 2007;4(10):e297.

19. DerSimonian R, Laird N. Meta-analysis in clinical trials. Control Clin Trials. 1986;7(3):177-88.

20. Gastelurrutia MA, Larrañaga B, Garay A, Echeveste Fde A, Fernandez-Llimos F. Impact of a program to reduce the dispensing of antibiotics without a prescription in Spain. Pharm Pract (Granada). 2013 Oct;11(4):185-90.

21. Al-Mohamadi A, Badr A, Bin Mahfouz L, Samargandi D, Al Ahdal A. Dispensing medications without prescription at Saudi community pharmacy: Extent and perception. Saudi Pharm J. 2013;21(1):13-8.

22. Nyazema N, Viberg N, Khoza S, Vyas S, Kumaranayake L, Tomson G, et al. Low sale of antibiotics without prescription: A cross-sectional study in Zimbabwean private pharmacies. J Antimicrob Chemother. 2007;59(4):718-26.

23. Salunkhe SD, Pandit VA, Dawane JS, Sarda KD, More CS. Study of over the counter sale of antimicrobials in pharmacy outlets in Pune, India: a cross sectional study. Int J Pharm Bio Sci. 2013;4(2):616-622.

24. Marković-Peković V, Grubiša N, Burger J, Bojanić L, Godman B. Initiatives to Reduce Nonprescription Sales and Dispensing of Antibiotics: Findings and Implications. J Res Pharm Pract. 2017;6(2):120-125.

25. Quagliarello AB1, Parry CM, Hien TT, Farrar JJ. Factors associated with carriage of penicillin-resistant Streptococcus pneumoniae among Vietnamese children: a ruralurban divide. J Health Popul Nutr. 2003;21(4):316-24.

26. Puspitasari HP1, Faturrohmah A, Hermansyah A. Do Indonesian community pharmacy workers respond to antibiotics requests appropriately? Trop Med Int Health. 2011;16(7):840-6.

27. Bin Abdulhak AA, Altannir MA, Almansor MA, Almohaya MS, Onazi AS, Marei MA, et al. Non prescribed sale of antibiotics in Riyadh, Saudi Arabia: a cross sectional study. BMC Public Health. 2011;11:538.

28. Bryce A, Hay AD, Lane IF, Thornton HV, Wootton M, Costelloe C. Global prevalence of antibiotic resistance in paediatric urinary tract infections caused by Escherichia coli and association with routine use of antibiotics in primary care: systematic review and meta-analysis. BMJ. 2016;352:i939.

29. World Health Organisation Critically important antimicrobials for human medicine 3rd revision 2011. Available from: http://apps.who.int/iris/bitstream/10665/77376/1/9789241504485 eng.pdf [Accessed 20 June 2017].

30. Kaakoush NO, Castaño-Rodríguez N, Mitchell HM, Man SM. Global Epidemiology of Campylobacter Infection. Clin Microbiol Rev. 2015;28(3):687-720.

31. Macy E. Penicillin and beta-lactam allergy: epidemiology and diagnosis. Curr Allergy Asthma Rep. 2014;14(11):476.

32. Santa-Ana-Tellez Y, Mantel-Teeuwisse AK, Dreser A, Leufkens HG, Wirtz VJ. Impact of over-the-counter restrictions on antibiotic consumption in Brazil and Mexico. PLoS One, 2013. 8(10):e75550. 
33. Bavestrello L, Cabello A, Casanova D. Impact of regulatory measures in the trends of community consumption of antibiotics in Chile. Rev Med Chil. 2002;130(11):1265-72.

34. Park S, Soumerai SB, Adams AS, Finkelstein JA, Jang S, Ross-Degnan D. Antibiotic use following a Korean national policy to prohibit medication dispensing by physicians. Health Policy Plan. 2005;20(5):302-9

35. International Pharmaceutical Federation (FIP). Fighting Antimicrobial Resistance: The Contribution of Pharmacists. 2015, The Hague: International Pharmaceutical Federation.

36. Houck PM, Bratzler DW, Nsa W, Ma A, Bartlett JG. Timing of antibiotic administration and outcomes for Medicare patients hospitalized with community-acquired pneumonia. Arch Intern Med. 2004;164(6):637-44.

37. Erku DA, Mekuria AB, Surur AS, Gebresillassie BM. Extent of dispensing prescription-only medications without a prescription in community drug retail outlets in Addis Ababa, Ethiopia: a simulated-patient study. Drug Healthc Patient Saf. 2016;8:65-70.

38. Hussain A, Ibrahim MIM, Malik M. Assessment of disease management of acute respiratory tract infection at community pharmacies through simulated visits in Pakistan. Latin American Journal of Pharmacy. 2012;31(10):1435-1440.

39. Almaaytah A, Mukattash TL, Hajaj J. Dispensing of non-prescribed antibiotics in Jordan. Patient Prefer Adherence. 2015;9:1389-95.

40. Marković-Peković V, Grubiša N. Self-medication with antibiotics in the Republic of Srpska community pharmacies: pharmacy staff behavior. Pharmacoepidemiol Drug Saf. 2012;21(10):1130-3

41. Plachouras D, Kavatha D, Antoniadou A, Giannitsioti E, Poulakou G, Kanellakopoulou K, Giamarellou H. Dispensing of antibiotics without prescription in Greece, 2008: another link in the antibiotic resistance chain. Euro Surveill. 2010;15(7). pii: 19488.

42. Shet A, Sundaresan S, Forsberg BC. Pharmacy-based dispensing of antimicrobial agents without prescription in India: appropriateness and cost burden in the private sector. Antimicrob Resist Infect Control. 2015;4:55

43. Volpato DE, de Souza BV, Dalla Rosa LG, Melo LH, Daudt CA, Deboni L. Use of antibiotics without medical prescription. Braz J Infect Dis. 2005;9(4):288-91.

44. Llor C, Cots JM. The sale of antibiotics without prescription in pharmacies in Catalonia, Spain. Clin Infect Dis. 2009;48(10):1345-9.

45. Al-Faham Z, Habboub G, Takriti F. The sale of antibiotics without prescription in pharmacies in Damascus, Syria. J Infect Dev Ctries. 2011;5(5):396-9.

46. Diwan V, Sabde YD, Byström E, De Costa A. Treatment of pediatric diarrhea: a simulated client study at private pharmacies of Ujjain, Madhya Pradesh, India. J Infect Dev Ctries. 2015;9(5):505-11.

47. Hoxha I, Malaj A, Tako R, Malaj L. Survey on how antibiotics are dispensed in community pharmacies in Albania. International Journal of Pharmacy and Pharmaceutical Sciences. 2015;7(7):449-450.

48. Chang J, Ye D, Lv B, Jiang M, Zhu S, Yan K, Tian Y, Fang Y. Sale of antibiotics without a prescription at community pharmacies in urban China: a multicentre crosssectional survey. J Antimicrob Chemother. 2017;72(4):1235-1242.

49. Saengcharoen W, Chongsuvivatwong V, Lerkiatbundit S, Wongpoowaraket P. Client and pharmacist factors affecting practice in the management of upper respiratory tract infection presented in community pharmacies: A simulated client study. Int J Pharm Pract. 2008;16(4):265-270. 
50. Contopoulos-Ioannidis DG, Koliofoti ID, Koutroumpa IC, Giannakakis IA, Ioannidis JP. Pathways for inappropriate dispensing of antibiotics for rhinosinusitis: a randomized trial. Clin Infect Dis. 2001;33(1):76-82.

51. Vacca CP1, Niño CY, Reveiz L. Restriction of antibiotic sales in pharmacies in Bogotá, Colombia: a descriptive study. Rev Panam Salud Publica. 2011;30(6):58691.

52. Chalker J, Chuc NT, Falkenberg T, Do NT, Tomson G. STD management by private pharmacies in Hanoi: practice and knowledge of drug sellers. Sex Transm Infect. 2000;76(4):299-302.

53. Kalungia AC, Burger J, Godman B, Costa JO, Simuwelu C. Non-prescription sale and dispensing of antibiotics in community pharmacies in Zambia. Expert Rev Anti Infect Ther. 2016;14(12):1215-1223.

54. Ibrahim MI, Palaian S, Al-Sulaiti F, El-Shami S. Evaluating community pharmacy practice in Qatar using simulated patient method: acute gastroenteritis management. Pharm Pract (Granada). 2016;14(4):800.

55. Chuc NT, Larsson M, Do NT, Diwan VK, Tomson GB, Falkenberg T. Improving private pharmacy practice: A multi-intervention experiment in Hanoi, Vietnam. $\mathrm{J}$ Clin Epidemiol. 2002;55(11):1148-55.

56. Jaganathan, M., et al., Non-prescription sale of antibiotics in pharmacies across Puducherry, India. International Journal of Basic \& Clinical Pharmacology. 2016;5(6):2403-2406.

57. Amin ME, Amine A, Newegy MS. Injudicious Provision of Subtherapeutic Doses of Antibiotics in Community Pharmacies. Innovations in Pharmacy. 2017;8(1):18.

58. Alabid AHMA, Ibrahim MIM, Hassali MA. Antibiotics dispensing for URTIs by community pharmacists and general medical practitioners in Penang, Malaysia: $A$ comparative study using simulated patients. Journal of Clinical and Diagnostic Research. 2014;8(1):119-123.

59. Malik M, Hassali MA, Shafie AA, Hussain A, Aljadhey H, Saleem F. Case management of malaria fever at community pharmacies in Pakistan: a threat to rational drug use. Pharm Pract (Granada). 2013;11(1):8-16

60. Bell CA, Pichenda K, llomäki J, Duncan GJ, Eang MT, Saini B. Responding to cough presentations: an interview study with Cambodian pharmacies participating in a National Tuberculosis Referral Program. J Eval Clin Pract. 2016;22(2):261-6

61. Al-Ghamdi MS. Empirical treatment of uncomplicated urinary tract infection by community pharmacist in the Eastern province of Saudi Arabia. Saudi Med J. 2001;22(12):1105-8.

62. Homedes N, Ugalde A. Mexican Pharmacies and Antibiotic Consumption at the USMexico Border. South Med Rev. 2012;5(2):9-19.

63. Okuyan B, Savan MA, Izzettin VF, Sancar M. Evaluation of rational antibiotic dispensing in the community pharmacy setting: a simulated patient study. Acta Pharm. Sci. 2017;55(2):7-16. 


\section{Box 1: Search strategy}

\# Searches

1 (antibiotic* ${ }^{*}$ or antimicrobial ${ }^{*}$ or antibacterial ${ }^{*}$ ).af.

2 (Non-prescri* or Sale* or Supply* or over the counter or Dispens* or Selfmedication).af.

3 (community pharmac* or Pharmacy or pharmacies or Pharmacy shop* or Retail

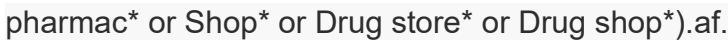

$4 \quad 1$ and 2 and 3

5 limit 4 to year="2000 -Current" 
Tables and figures

3289 records identified through database searching (Medline 795, EMBASE 2328,

CINAHL 166)
13 additional records identified through other sources

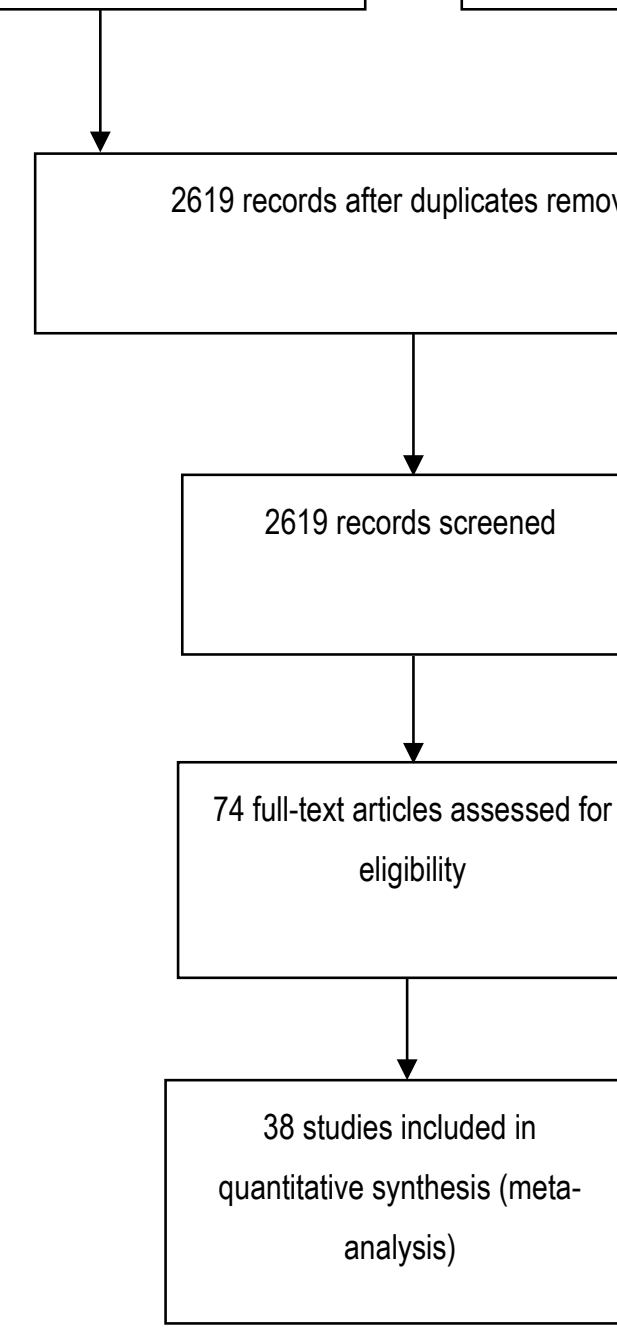

2545 records excluded after reading titles and abstracts

36 full-text articles excluded

Opinion-based survey $(n=14)$

Duplicate reports $(n=2)$

Reviews and letters $(n=7)$

Conference abstract $(\mathrm{n}=2)$

Qualitative studies $(n=6)$

No relevant data $(n=5)$

Figure 1: Flow diagram of article selection process 
Table 1 Characteristics of included studies

\begin{tabular}{|c|c|c|c|c|c|c|c|}
\hline Authors & $\begin{array}{l}\text { Study } \\
\text { location }\end{array}$ & Study design & Methods & $\begin{array}{l}\text { Number of } \\
\text { community } \\
\text { pharmacies } \\
\text { involved }\end{array}$ & $\begin{array}{l}\text { Number of } \\
\text { interactions } \\
\text { or } \\
\text { consultations }\end{array}$ & $\begin{array}{l}\text { Proportion of } \\
\text { dispensing of } \\
\text { non- } \\
\text { prescribed } \\
\text { antibiotics } \\
(\%)\end{array}$ & $\begin{array}{l}\text { Risk of bias } \\
\text { classification }\end{array}$ \\
\hline Hussain et al., ${ }^{38}$ & Pakistan & $\begin{array}{l}\text { Cross- } \\
\text { sectional }\end{array}$ & $\begin{array}{l}\text { Simulated patient visits } \\
\text { involving scenarios of } \\
\text { symptom of upper } \\
\text { respiratory tract infections } \\
\text { (URTI) }\end{array}$ & 371 & 371 & 57.4 & Moderate \\
\hline $\begin{array}{l}\text { Puspitasari et } \\
\text { al., }{ }^{26}\end{array}$ & Indonesia & $\begin{array}{l}\text { Cross- } \\
\text { sectional }\end{array}$ & $\begin{array}{l}\text { Simulated patient visits } \\
\text { involving specific product } \\
\text { request (ciprofloxacin } \\
\text { tablets and tetracycline } \\
\text { capsules) }\end{array}$ & 88 & 176 & 90.9 & Low \\
\hline $\begin{array}{l}\text { Almaaytah et } \\
\text { al., }{ }^{39}\end{array}$ & Jordan & $\begin{array}{l}\text { Cross- } \\
\text { sectional }\end{array}$ & $\begin{array}{l}\text { Simulated patient visits } \\
\text { involving scenarios of } \\
\text { symptom of URTI, } \\
\text { gastroenteritis and urinary } \\
\text { tract infection (UTI) in } \\
\text { women of childbearing age }\end{array}$ & 202 & 202 & 74.3 & Low \\
\hline $\begin{array}{l}\text { Gastelurrutia et } \\
\text { al., }{ }^{20}\end{array}$ & Spain & $\begin{array}{l}\text { Cross- } \\
\text { sectional }\end{array}$ & $\begin{array}{l}\text { Simulated patient visits } \\
\text { involving specific product } \\
\text { requests and scenarios of } \\
\text { symptoms of UTI in } \\
\text { women of childbearing age }\end{array}$ & 280 & 280 & $\begin{array}{l}\text { Product } \\
\text { requests } \\
(16.3) \text { and } \\
\text { symptom- } \\
\text { based } \\
\text { scenarios } \\
(18.7)\end{array}$ & Moderate \\
\hline $\begin{array}{l}\text { Marković- } \\
\text { Peković and } \\
\text { Grubisa, }{ }^{40}\end{array}$ & $\begin{array}{l}\text { Bosnia and } \\
\text { Herzegovina }\end{array}$ & $\begin{array}{l}\text { Cross- } \\
\text { sectional }\end{array}$ & $\begin{array}{l}\text { Simulated patient visits } \\
\text { involving scenarios of } \\
\text { symptoms of URTI }\end{array}$ & 131 & 131 & 58 & Moderate \\
\hline
\end{tabular}




\begin{tabular}{|c|c|c|c|c|c|c|c|}
\hline $\begin{array}{l}\text { Plachouras et } \\
\text { al., } 41\end{array}$ & Greece & $\begin{array}{l}\text { Cross- } \\
\text { sectional }\end{array}$ & $\begin{array}{l}\text { Simulated patient visits } \\
\text { involving specific product } \\
\text { requests } \\
\text { (amoxicillin/clavulanate } \\
\text { acid or ciprofloxacin) }\end{array}$ & 174 & 174 & 72.4 & Moderate \\
\hline $\begin{array}{l}\text { Quagliarello et } \\
\text { al., } 25\end{array}$ & Vietnam & $\begin{array}{l}\text { Cross- } \\
\text { sectional }\end{array}$ & $\begin{array}{l}\text { Simulated patient visits } \\
\text { involving scenarios of } \\
\text { symptoms of URTI and } \\
\text { gastroenteritis in children }\end{array}$ & 75 & 150 & 86.7 & Low \\
\hline Shet et al., ${ }^{42}$ & India & $\begin{array}{l}\text { Cross- } \\
\text { sectional }\end{array}$ & $\begin{array}{l}\text { Simulated patient visits } \\
\text { involving scenarios of } \\
\text { symptoms of URTI in } \\
\text { adults and gastroenteritis } \\
\text { in children }\end{array}$ & 261 & 261 & 66.7 & Low \\
\hline Volpato et al., ${ }^{43}$ & Brazil & $\begin{array}{l}\text { Cross- } \\
\text { sectional }\end{array}$ & $\begin{array}{l}\text { Simulated patient visits } \\
\text { involving scenarios of } \\
\text { symptoms of URTI }\end{array}$ & 107 & 107 & 74 & Moderate \\
\hline Llor \& Cots, ${ }^{44}$ & Spain & $\begin{array}{l}\text { Cross- } \\
\text { sectional }\end{array}$ & $\begin{array}{l}\text { Simulated patient visits } \\
\text { involving scenarios of } \\
\text { symptoms of URTI, acute } \\
\text { bronchitis and UTI in } \\
\text { women of childbearing age }\end{array}$ & 197 & 197 & 45.2 & Low \\
\hline $\begin{array}{l}\text { Bin Abdulhak et } \\
\text { al., } 27\end{array}$ & $\begin{array}{l}\text { Saudi } \\
\text { Arabia }\end{array}$ & $\begin{array}{l}\text { Cross- } \\
\text { sectional }\end{array}$ & $\begin{array}{l}\text { Simulated patient visits } \\
\text { involving scenarios of } \\
\text { symptoms of URTI, acute } \\
\text { bronchitis, otitis media, } \\
\text { gastroenteritis and UTI in } \\
\text { women of childbearing age } \\
\text { aged women) }\end{array}$ & 327 & 327 & 77.6 & Moderate \\
\hline $\begin{array}{l}\text { Al-Faham et al., } \\
45\end{array}$ & Syria & $\begin{array}{l}\text { Cross- } \\
\text { sectional }\end{array}$ & $\begin{array}{l}\text { Simulated patient visits } \\
\text { involving scenarios of } \\
\text { symptoms of URTI }\end{array}$ & 200 & 200 & 87 & Moderate \\
\hline
\end{tabular}




\begin{tabular}{|c|c|c|c|c|c|c|c|}
\hline Erku et al., ${ }^{37}$ & Ethiopia & $\begin{array}{l}\text { Cross- } \\
\text { sectional }\end{array}$ & $\begin{array}{l}\text { Simulated patient visits } \\
\text { involving specific product } \\
\text { requests (amoxicillin and } \\
\text { clavulanic acid capsule) } \\
\text { and scenarios of } \\
\text { symptoms of URTI }\end{array}$ & 31 & 62 & $\begin{array}{l}\text { Product } \\
\text { requests } \\
(93.5) \text { and } \\
\text { symptom- } \\
\text { based } \\
\text { scenarios } \\
(77.4)\end{array}$ & Moderate \\
\hline Diwan et al., ${ }^{46}$ & India & $\begin{array}{l}\text { Cross- } \\
\text { sectional }\end{array}$ & $\begin{array}{l}\text { Simulated patient visits } \\
\text { involving scenarios of } \\
\text { symptoms of } \\
\text { gastroenteritis in children }\end{array}$ & 164 & 164 & 40.2 & Moderate \\
\hline Hoxha et al., ${ }^{47}$ & Albania & cross-sectional & Specific product request & 323 & 323 & 80.2 & Moderate \\
\hline Chang et al., ${ }^{48}$ & China & cross-sectional & $\begin{array}{l}\text { Simulated patient visits } \\
\text { involving scenarios of } \\
\text { symptoms of URTI in } \\
\text { adults and gastroenteritis } \\
\text { in children }\end{array}$ & 256 & 512 & 68.8 & Low \\
\hline $\begin{array}{l}\text { Saengcharoen et } \\
\text { al., } 49\end{array}$ & Thailand & $\begin{array}{l}\text { Cross- } \\
\text { sectional }\end{array}$ & $\begin{array}{l}\text { Simulated patient visits } \\
\text { involving scenarios of } \\
\text { symptoms of URTI }\end{array}$ & 32 & 128 & 87.5 & Low \\
\hline $\begin{array}{l}\text { Contopoulos- } \\
\text { loannidis et al., } \\
{[50]}\end{array}$ & Greece & $\begin{array}{l}\text { Cross- } \\
\text { sectional }\end{array}$ & $\begin{array}{l}\text { Simulated patient visits } \\
\text { involving scenarios of } \\
\text { symptoms of URTI }\end{array}$ & 98 & 98 & 77.6 & Low \\
\hline Vacca et al., ${ }^{51}$ & Columbia & cross-sectional & $\begin{array}{l}\text { Simulated patient visits } \\
\text { involving specific product } \\
\text { requests (amoxicillin, } \\
\text { azithromycin, ciprofloxacin } \\
\text { and trimethoprim / } \\
\text { sulfamethoxazole ) and } \\
\text { scenarios of symptoms of } \\
\text { URTI, gastroenteritis, otitis } \\
\text { media and UTI }\end{array}$ & 200 & 239 & 80.3 & Low \\
\hline
\end{tabular}




\begin{tabular}{|c|c|c|c|c|c|c|c|}
\hline $\begin{array}{l}\text { Saengcharoen \& } \\
\text { Lerkiatbundit, }{ }^{14}\end{array}$ & Thailand & cross-sectional & $\begin{array}{l}\text { Simulated patient visits } \\
\text { involving scenarios of } \\
\text { symptoms of acute } \\
\text { gastroenteritis in children }\end{array}$ & 115 & 115 & 52.2 & Low \\
\hline $\begin{array}{l}\text { Al-Mohamadi et } \\
\text { al., } 21\end{array}$ & $\begin{array}{l}\text { Saudi } \\
\text { Arabia }\end{array}$ & $\begin{array}{l}\text { Cross- } \\
\text { sectional }\end{array}$ & $\begin{array}{l}\text { Simulated patient visits } \\
\text { involving specific product } \\
\text { requests (co-amoxiclav or } \\
\text { cefaclor). }\end{array}$ & 60 & 60 & 97.6 & Moderate \\
\hline $\begin{array}{l}\text { Guinovart et al., } \\
10\end{array}$ & Spain & $\begin{array}{l}\text { Cross- } \\
\text { sectional }\end{array}$ & $\begin{array}{l}\text { Simulated patient visits } \\
\text { involving scenarios of } \\
\text { symptoms of URTI, acute } \\
\text { bronchitis and UTI in } \\
\text { women of childbearing } \\
\text { age. }\end{array}$ & 220 & 220 & 54.1 & Moderate \\
\hline Chalker et al., ${ }^{52}$ & Vietnam & cross-sectional & $\begin{array}{l}\text { Simulated patient visits } \\
\text { involving scenarios of } \\
\text { symptoms of sexually } \\
\text { transmitted diseases } \\
\text { (STD) }\end{array}$ & 60 & 295 & 81.5 & Moderate \\
\hline Kalungia et al., ${ }^{53}$ & Zambia & $\begin{array}{l}\text { Cross- } \\
\text { sectional }\end{array}$ & $\begin{array}{l}\text { structured interviewer- } \\
\text { administered questionnaire } \\
\text { with simulated case } \\
\text { scenarios of symptoms of } \\
\text { URTI and UTI in } \\
\text { pregnancy }\end{array}$ & 73 & 146 & 71.2 & Moderate \\
\hline Ibrahim et al., ${ }^{54}$ & Qatar & cross-sectional & $\begin{array}{l}\text { Simulated patient visits } \\
\text { involving scenarios of } \\
\text { symptoms of acute } \\
\text { gastroenteritis }\end{array}$ & 30 & 60 & 43.9 & Moderate \\
\hline Chuc et al., 55 & Vietnam & $\begin{array}{l}\text { Randomized } \\
\text { controlled trial }\end{array}$ & $\begin{array}{l}\text { Simulated patient visits } \\
\text { involving specific product } \\
\text { requests and scenarios of } \\
\text { symptoms of } \\
\text { uncomplicated URTI in a } \\
\text { child and STD in an adult } \\
\text { in an adult man }\end{array}$ & 58 & 116 & $\begin{array}{l}\text { Product } \\
\text { requests } \\
(94.8) \text { and } \\
\text { symptom- } \\
\text { based } \\
\text { scenarios } \\
(41.1)\end{array}$ & Low \\
\hline
\end{tabular}




\begin{tabular}{|c|c|c|c|c|c|c|c|}
\hline $\begin{array}{l}\text { Salunkhe et al., } \\
23\end{array}$ & India & cross-sectional & $\begin{array}{l}\text { Simulated patient visits } \\
\text { involving scenarios of } \\
\text { symptoms of URTI or } \\
\text { diarrhoea }\end{array}$ & 263 & 263 & 94.3 & Moderate \\
\hline $\begin{array}{l}\text { Jaganathan et } \\
\text { al., } 56\end{array}$ & India & $\begin{array}{l}\text { Cross- } \\
\text { sectional }\end{array}$ & $\begin{array}{l}\text { Simulated patient visits } \\
\text { involving scenarios of } \\
\text { symptoms of acute } \\
\text { gastroenteritis and URTI }\end{array}$ & 120 & 120 & 72.5 & Moderate \\
\hline Amin et al., 57 & Egypt & $\begin{array}{l}\text { Cross- } \\
\text { sectional }\end{array}$ & $\begin{array}{l}\text { Simulated patient visits } \\
\text { involving scenarios of } \\
\text { symptoms of URTI }\end{array}$ & 104 & 104 & 65.4 & Low \\
\hline $\begin{array}{l}\text { Satyanarayana } \\
\text { et al., } 15\end{array}$ & India & $\begin{array}{l}\text { Cross- } \\
\text { sectional }\end{array}$ & $\begin{array}{l}\text { Simulated patient visits } \\
\text { involving scenarios of } \\
\text { symptoms of pulmonary } \\
\text { tuberculosis (TB) }\end{array}$ & 622 & 1200 & 27 & Low \\
\hline $\begin{array}{l}\text { Nyazema et al., } \\
22\end{array}$ & Zimbabwe & $\begin{array}{l}\text { Cross- } \\
\text { sectional }\end{array}$ & $\begin{array}{l}\text { Simulated patient visits } \\
\text { involving scenarios of } \\
\text { symptoms of STD and } \\
\text { gastroenteritis }\end{array}$ & 87 & 184 & 8.2 & Moderate \\
\hline Alabid et al., ${ }^{58}$ & Malaysia & $\begin{array}{l}\text { Cross- } \\
\text { sectional }\end{array}$ & $\begin{array}{l}\text { Simulated patient visits } \\
\text { involving scenarios of } \\
\text { symptoms of URTI }\end{array}$ & 50 & 100 & 32 & Moderate \\
\hline Malik et al., 59 & Pakistan & $\begin{array}{l}\text { Cross- } \\
\text { sectional }\end{array}$ & $\begin{array}{l}\text { Simulated patient visits } \\
\text { involving scenarios of } \\
\text { symptoms of malaria }\end{array}$ & 238 & 238 & 28.6 & Moderate \\
\hline Bell et al., ${ }^{60}$ & Cambodia & $\begin{array}{l}\text { Cross- } \\
\text { sectional }\end{array}$ & $\begin{array}{l}\text { Interviewer-administered } \\
\text { questionnaire with } \\
\text { simulated case scenarios } \\
\text { of TB }\end{array}$ & 170 & 170 & 24.1 & Low \\
\hline Al-Ghamdi 61 & $\begin{array}{l}\text { Saudi } \\
\text { Arabia }\end{array}$ & $\begin{array}{l}\text { Cross- } \\
\text { sectional }\end{array}$ & $\begin{array}{l}\text { Simulated patient visits } \\
\text { involving scenarios of } \\
\text { symptoms of UTI }\end{array}$ & 88 & 88 & 81.8 & Moderate \\
\hline
\end{tabular}




\begin{tabular}{|c|c|c|c|c|c|c|c|}
\hline $\begin{array}{l}\text { Homedes and } \\
\text { Ugalde, }{ }^{62}\end{array}$ & Mexico & $\begin{array}{l}\text { Cross- } \\
\text { sectional }\end{array}$ & $\begin{array}{l}\text { Interviewer-administered } \\
\text { questionnaire with } \\
\text { simulated case scenarios } \\
\text { of URTI and gastroenteritis }\end{array}$ & 25 & 49 & 71.4 & Moderate \\
\hline $\begin{array}{l}\text { Marković- } \\
\text { Peković et al } 24\end{array}$ & $\begin{array}{l}\text { Bosnia and } \\
\text { Herzegovina }\end{array}$ & $\begin{array}{l}\text { Cross- } \\
\text { sectional }\end{array}$ & $\begin{array}{l}\text { Simulated patient visits } \\
\text { involving scenarios of } \\
\text { symptoms of URTI }\end{array}$ & 383 & 383 & 18.5 & Low \\
\hline Okuyan et al ${ }^{63}$ & Turkey & $\begin{array}{l}\text { Cross- } \\
\text { sectional }\end{array}$ & $\begin{array}{l}\text { Simulated patient visits } \\
\text { involving scenarios of } \\
\text { symptoms of URTI }\end{array}$ & 70 & 70 & 45.7 & Moderate \\
\hline
\end{tabular}




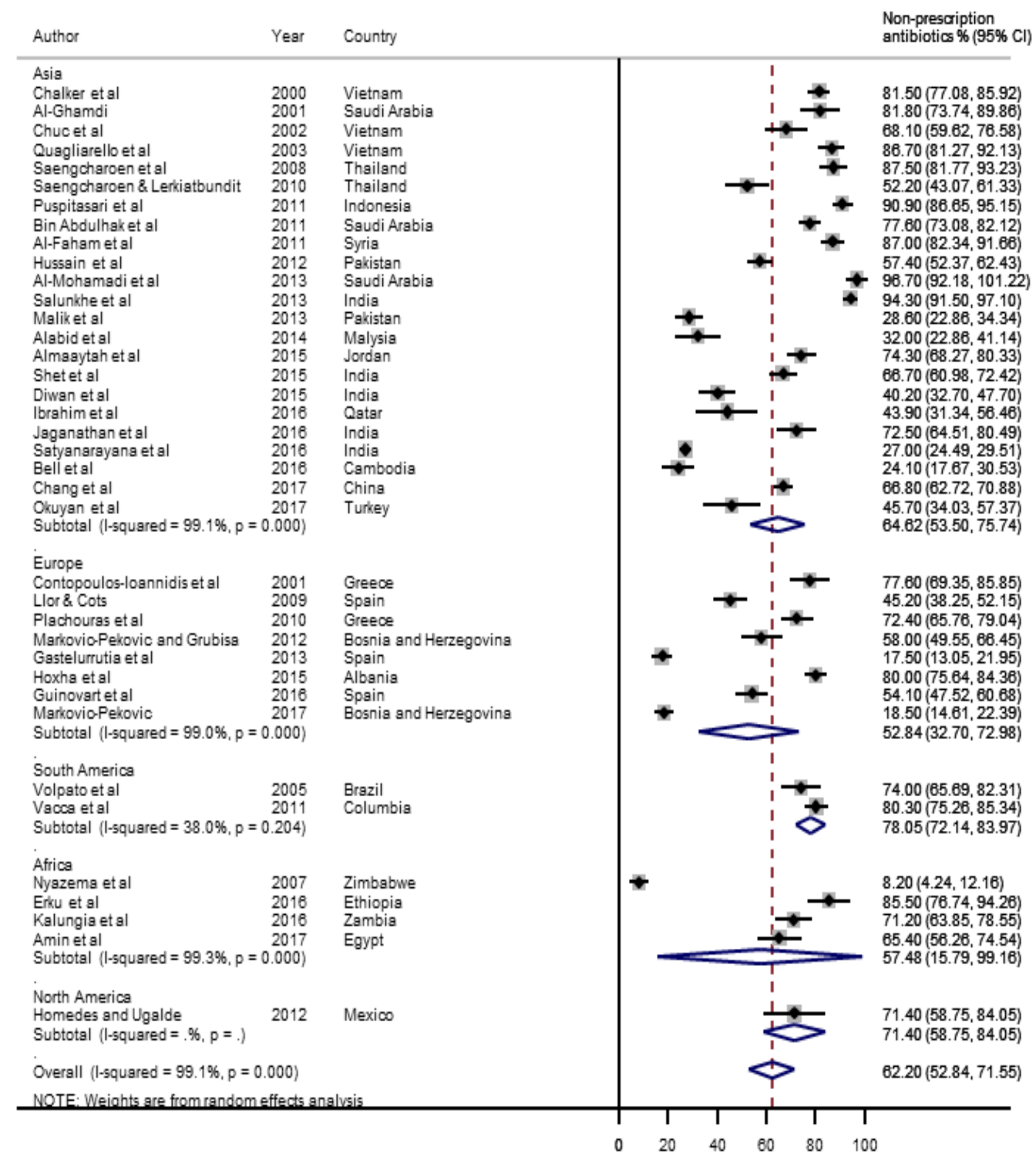

Figure 2: Meta-analysis for the overall pooled proportion of non-prescription supply of antibiotics 


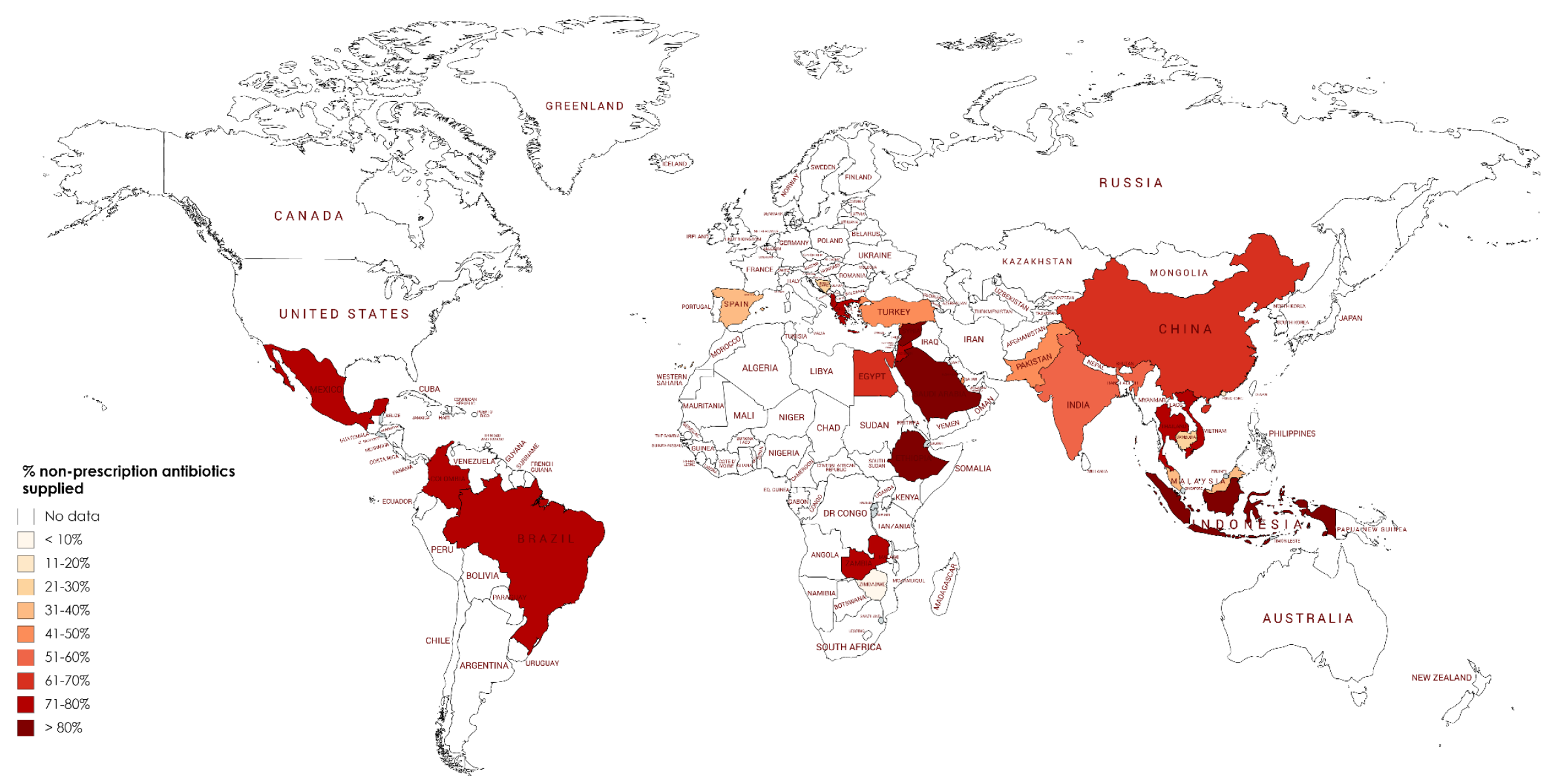

Figure 3: Country level estimates of non-prescription supply of antibiotics 


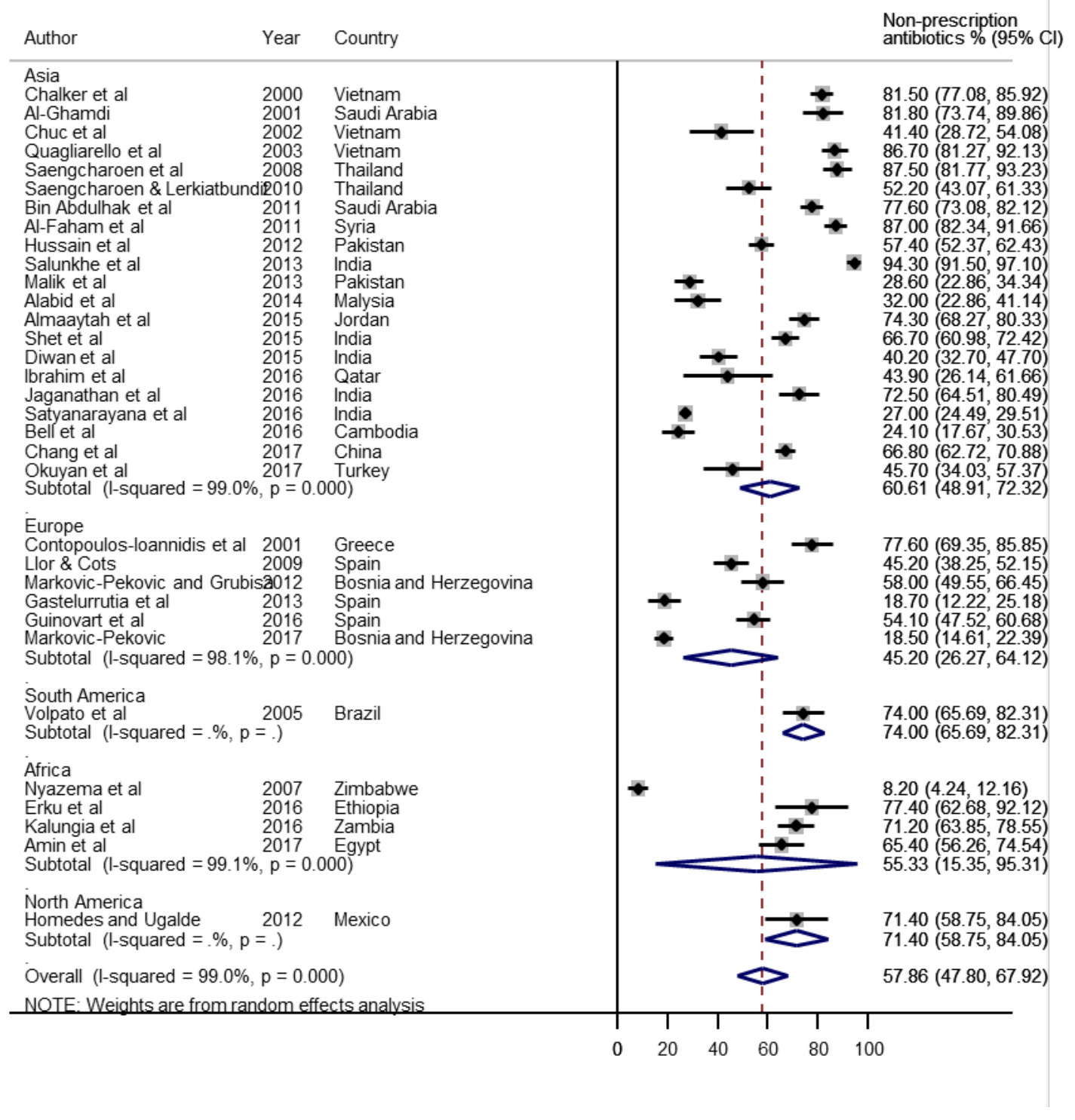

Figure 4: Meta-analysis for the proportion of non-prescription supply of antibiotics based on pharmacy staff recommendation 
Table 2: Subgroup meta-analysis of the proportion of non-prescription supply of antibiotics

\begin{tabular}{|c|c|c|c|}
\hline Subgroup & Estimate \% $(95 \% \mathrm{Cl})$ & No. studies & Heterogeneity \\
\hline \multicolumn{4}{|l|}{ Region } \\
\hline Asia & $65(54-76)$ & 23 & $I^{2}=99.1 \%, p<0.001$ \\
\hline Africa & $57(16-99)$ & 4 & $I^{2}=99.3 \%, p<0.001$ \\
\hline Europe & $53(33-73)$ & 8 & $\mathrm{I}^{2}=98.7 \%, p<0.001$ \\
\hline South America & $78(72-84)$ & 2 & $I^{2}=38.0 \%, p=0.204$ \\
\hline North America & $71(59-84)$ & 1 & ND \\
\hline \multicolumn{4}{|l|}{ Study period } \\
\hline $2011-2017$ & $56(43-69)$ & 7 & $I^{2}=99.1 \%, p<0.001$ \\
\hline $2006-2010$ & $62(43-81)$ & 12 & $I^{2}=99.4 \%, p<0.001$ \\
\hline $2000-2005$ & $80(76-85)$ & 19 & $I^{2}=71.8 \%, p=0.002$ \\
\hline \multicolumn{4}{|l|}{ Number of community } \\
\hline \multicolumn{4}{|l|}{ pharmacies included } \\
\hline$\geq 100$ & $58(46-70)$ & 23 & $I^{2}=99.2 \%, p<0.001$ \\
\hline$<100$ & $69(52-85)$ & 15 & $\mathrm{I}^{2}=99.0 \%, \mathrm{p}<0.001$ \\
\hline \multicolumn{4}{|l|}{ Type of scenario } \\
\hline Direct product request & $85(75-94)$ & 4 & $I^{2}=93.9 \%, p<0.001$ \\
\hline Symptom-based & $59(49-70)$ & 30 & $\mathrm{I}^{2}=99.1 \%, p<0.001$ \\
\hline Mixed $^{*}$ & $63(26-99)$ & 4 & $I^{2}=99.3 \%, p<0.001$ \\
\hline \multicolumn{4}{|l|}{$\begin{array}{l}\text { Category of pharmacy } \\
\text { staff }\end{array}$} \\
\hline Pharmacist only & $59(32-87)$ & 5 & $I^{2}=98.2 \%, p<0.001$ \\
\hline Mixed $^{* *}$ & $58(42-74)$ & 12 & $\mathrm{I}^{2}=99.0 \%, p<0.001$ \\
\hline Unspecified & $65(52-78)$ & 21 & $I^{2}=99.3 \%, p<0.001$ \\
\hline \multicolumn{4}{|l|}{ Concealment in } \\
\hline Yes & $63(53-73)$ & 35 & $I^{2}=99.1 \%, p<0.001$ \\
\hline No & $55(21-90)$ & 3 & $I^{2}=98.1 \%, p<0.001$ \\
\hline
\end{tabular}


Table 3: Pooled estimates on the proportion of antibiotics supplied without a prescription by disease category

\begin{tabular}{lccc}
\hline Symptom category & Estimate \% (95\% Cl) & No. studies & Heterogeneity \\
\hline URTI & $67(55-79)$ & 23 & $\mathrm{I}^{2}=98.7 \%, \mathrm{p}<0.001$ \\
Bronchitis & $42(34-49)$ & 2 & $\mathrm{I}^{2}=98.5 \%, \mathrm{p}<0.001$ \\
Otitis media & $57(47-68)$ & 2 & $\mathrm{I}^{2}=57.0 \%, \mathrm{p}=0.127$ \\
Gastroenteritis & $63(46-80)$ & 12 & $\mathrm{I}^{2}=98.6 \%, \mathrm{p}<0.001$ \\
UTI & $68(42-93)$ & 6 & $\mathrm{I}^{2}=97.8 \%, \mathrm{p}<0.001$ \\
STD & $47(44-51)$ & 2 & $\mathrm{I}^{2}=99.8 \%, \mathrm{p}<0.001$ \\
Pulmonary TB & $27(24-29)$ & 2 & $\mathrm{I}^{2}=0.0 \%, \mathrm{p}=0.410$ \\
Malaria & $29(23-34)$ & 1 & $\mathrm{ND}$ \\
\hline
\end{tabular}

ND - not determined

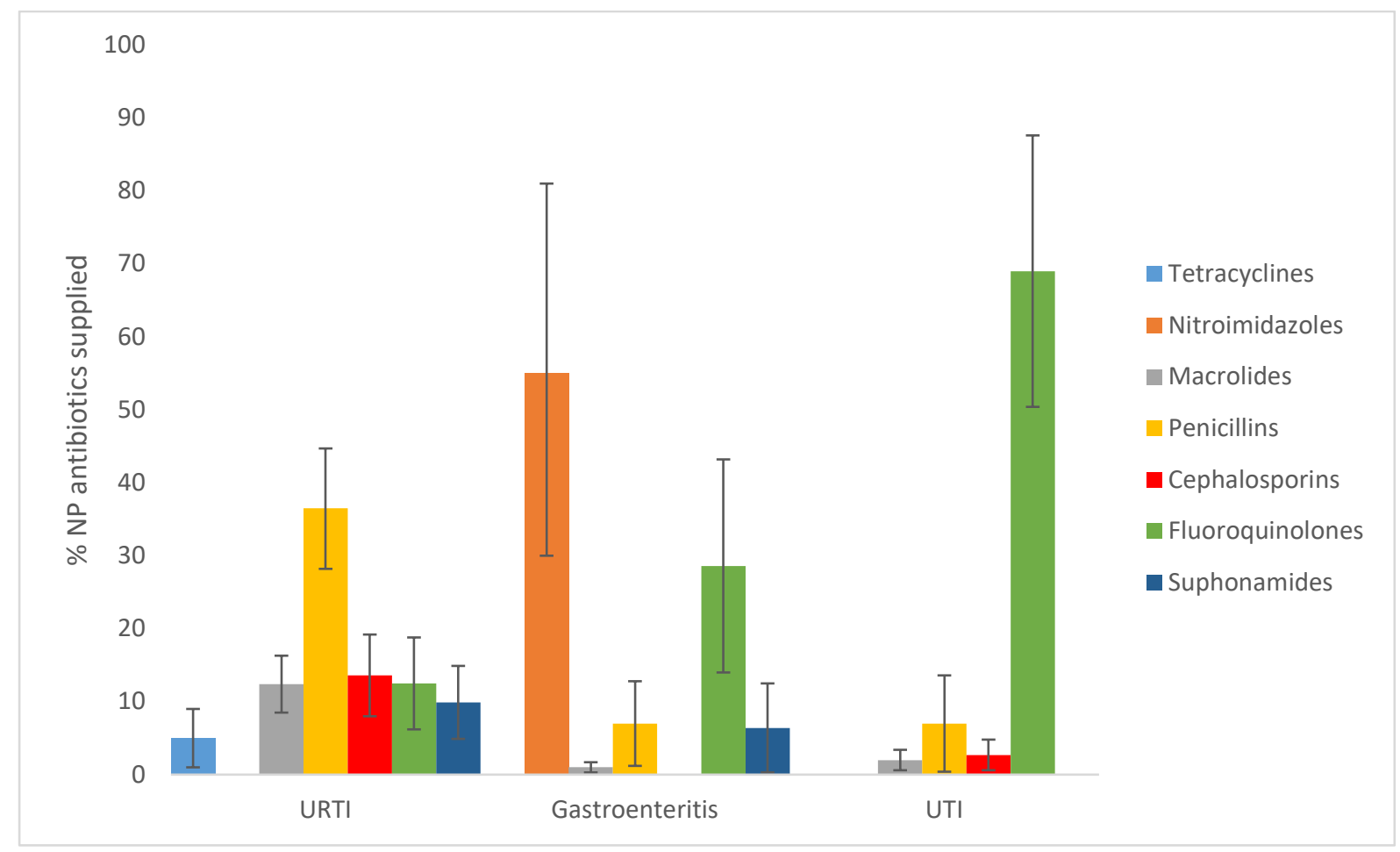

Figure 5: Classes of antibiotics supplied without prescription for Gastroenteritis, URTI and UTI 
Table 4: Nature of counselling provided during consultation

\begin{tabular}{|c|c|c|c|}
\hline Nature of counselling & Estimate \% (95\% Cl) & No. studies & Heterogeneity \\
\hline $\begin{array}{l}\text { Asked patients about } \\
\text { allergy }\end{array}$ & $32(11-53)$ & 10 & $\mathrm{I}^{2}=99.4 \%, p<0.001$ \\
\hline $\begin{array}{l}\text { Asked patients about } \\
\text { any medicines they are } \\
\text { taking }\end{array}$ & $12(4-19)$ & 6 & $I^{2}=96.1 \%, p<0.001$ \\
\hline $\begin{array}{l}\text { Asked female patients } \\
\text { of child-bearing age } \\
\text { about pregnancy status }\end{array}$ & $8(1-18)$ & 4 & $\mathrm{I}^{2}=82.5 \%, p=0.003$ \\
\hline $\begin{array}{l}\text { Explained the dose of } \\
\text { antibiotics }\end{array}$ & $73(52-92)$ & 11 & $\mathrm{I}^{2}=99.2 \%, p<0.001$ \\
\hline $\begin{array}{l}\text { Explained how long to } \\
\text { take the antibiotics }\end{array}$ & $49(28-70)$ & 12 & $\mathrm{I}^{2}=99.2 \%, p<0.001$ \\
\hline $\begin{array}{l}\text { Referred patients to a } \\
\text { physician }\end{array}$ & $21(14-28)$ & 16 & $\mathrm{I}^{2}=97.8 \%, p<0.001$ \\
\hline
\end{tabular}

